九州大学学術情報リポジトリ

Kyushu University Institutional Repository

\title{
Growth Response of Rice and Paddy Weeds Under Elevated Temperatures
}

Won, 0k Jae

Department of Bioproduction Environmental Sciences, Faculty of Agriculture, Kyushu University | Department of Crop Science, Chungnam National University

Eom, Min Young

Department of Bioproduction Environmental Sciences, Faculty of Agriculture, Kyushu University | Department of Crop Science, Chungnam National University

Kim, Young Tae

Department of Bioproduction Environmental Sciences, Faculty of Agriculture, Kyushu University | Department of Crop Science, Chungnam National University

Bir, Md. Shahidul Haque

Department of Bioproduction Environmental Sciences, Faculty of Agriculture, Kyushu University | Department of Crop Science, Chungnam National University

他

https://doi.org/10.5109/1799303

出版情報 : 九州大学大学院農学研究院紀要. 62 (1)，pp.63-67，2017-02-24. Faculty of Agriculture， Kyushu University

バージョン :

権利関係: 


\title{
Growth Response of Rice and Paddy Weeds Under Elevated Temperatures
}

\section{Ok Jae WON ${ }^{1}$, Min Young EOM ${ }^{1}$, Young Tae KIM ${ }^{1}$, Md. Shahidul Haque BIR ${ }^{1}$, Tae Seon PARK ${ }^{2}$, Md. Romij UDDIN ${ }^{3}$, Taek-Keun OH $^{4}$ *, Yoshiyuki SHINOGI ${ }^{5}$ and Kee Woong PARK ${ }^{1, *}$}

\author{
Department of Bioproduction Environmental Sciences, Faculty of Agriculture, Kyushu University, \\ Hakozaki 6-10-1 Higashi-Ku, Fukuoka City 812-8581, Japan \\ (Received October 28, 2016 and accepted November 4, 2016)
}

\begin{abstract}
This study was conducted to investigate the growth response of rice and annual paddy weeds under elevated temperatures. In the context of climate change, temperature is one of the most important climatic factors influencing the growth of crops as well as weeds. Rice and three major annual paddy weeds (Monochoria vaginalis, Echinochloa crus-galli, and Ludwigia prostrata) were grown under different temperature regimes (ambient, ambient $+0.8^{\circ} \mathrm{C}$, ambient $+1.9^{\circ} \mathrm{C}$, and ambient $+3.4^{\circ} \mathrm{C}$ ). Results revealed that the growth of rice and three annual paddy weed species increased with the temperature rise in the phytotrons. Above ground dry weight of rice was 1.31, 1.67, and 1.73 times higher at ambient $+0.8,+1.9$ and $+3.4^{\circ} \mathrm{C}$, respectively, than it was at ambient. Similar growth responses to rice was observed in E. crusgalli and $M$. vaginalis under the elevated temperatures. L. prostrate exhibited the most significant increases in leaf stage, leaf area, plant height, and plant dry weight, which were, respectively, 2.94, 3.57, 1.69 and 2.86 times higher at ambient $+3.4^{\circ} \mathrm{C}$ than at ambient. Our findings suggest that climate change in the form of instant rising of temperatures might have an influence on the growth of rice and weeds and might confer relatively low competitive ability to rice.
\end{abstract}

Key words: Climate change, paddy weeds, rice, temperature

\section{INTRODUCTION}

The impacts of climate change are global concerns. The emission of greenhouse gases from agricultural systems is a main source of global temperature increase. Global warming is not uniformly experienced throughout the world. It is reported that the global temperature is predicted to warm by an average of $0.3^{\circ} \mathrm{C}$ to $4.8^{\circ} \mathrm{C}$ by the end of the 21 st century with a likely increase of at least $1.5^{\circ} \mathrm{C}$ (IPCC 2013). Climate change has great potential to threaten the productivity and growth, as well as the production systems, of a wide range of crop species, especially those grown in open field systems (Rosenzweig et al., 2001).

In rice, extreme temperatures are of particular importance during flowering which usually lasts two to three weeks. Exposure to high temperatures for a few hours can dramatically reduce pollen viability and, subsequently, result in yield loss. Osada et al. (1973) and Matsui et al. (1997) reported that spikelet sterility was significantly increased at temperatures higher than $35^{\circ} \mathrm{C}$.

Climate change not only influences the ecology of crops but also that of weeds. It is more likely for weeds

\footnotetext{
1 Department of Crop Science, Chungnam National University, Daejeon 34134, Korea

National Institute of Crop Science, RDA, Wanju, 55365, Korea Department of Agronomy Bangladesh Agricultural University, Mymensingh-2202, Bangladesh

${ }^{4}$ Department of Bio-Environmental Chemistry, Chungnam National University, Daejeon 34134, Korea

5 Department of Bioproduction Environmental Sciences, Faculty of Agriculture, Kyushu University, Hakozaki 6-10-1, HigashiKu, Fukuoka City 812-8581, Japan

* Corresponding author (E-mail: ok5382@cnu.ac.kr) (T.K. Oh)

* Corresponding author (E-mail: parkkw@cnu.ac.kr) (K.W. Park)
}

than crops to show positive growth and reproductive responses when faced with changes in resources (water, nutrients, light, and $\mathrm{CO}_{2}$ ) within climatic conditions due to their greater potential to adapt. Liu et al. (2008) found that temperature had a great influence on distribution, yield, and quality of soybean; their study demonstrated the great sensitivity of soybean to temperature change. Likewise, higher temperature levels also affect weed growth and development. Temperature is reported to affect strongly the geographical distribution of weeds (Patterson et al., 1979; Wolfe et al., 2008). It was reported that, with an increase of $3^{\circ} \mathrm{C}$ in temperature, the biomass and leaf area of itchgrass (Rottboellia cochinchinensis) increased by $88 \%$ and $68 \%$, respectively (Patterson et al., 1979).

Weeds are one of the major causes of yield reduction in rice production everywhere in the world. It was found that weeds might be the reason for the annual rice yield reduction in sub-Saharan Africa by at least 2.2 million tons; equating to a US $\$ 1.45$ billion loss (Rodenburg and Johnson 2009). Globally, yield losses due to pests and diseases have been estimated at approximately $40 \%$ of which weeds caused the highest loss (32\%) (Rao et al., 2007). Monochoria vaginalis, Echinochloa crus-galli, and Ludwigia prostrata are the most important paddy weed species in rice cultivation in China, Japan and Korea. These weeds are of particular concern as they are the most dominant paddy weeds in Korea (Park et al., 2002; Won et al., 2015).

Many studies have shown that high temperatures can reduce grain yield (Ziska et al., 1996; Matsui et al., 1997; Horie et al., 2000; Prasad et al., 2006; Sung et al., 2014) owing to significantly increased spikelet sterility (Kim et al., 1996; Matsui et al., 1997; Jagadish et al., 2007; Ohe et al., 2007). However, limited numbers of 
studies have been conducted on the effect of elevated temperatures on rice and weed species. This study was undertaken to examine the response of rice and paddy weeds to elevated temperatures which may have a positive effect on their growth.

\section{MATERIALS AND METHODS}

\section{Study Site}

The experiment was conducted at the experimental farm in Chungnam National University, Daejeon, Korea $\left(127^{\circ} 21^{\prime} \mathrm{E}, 36^{\circ} 22^{\prime} \mathrm{N}\right.$, alt. $\left.34 \mathrm{~m}\right)$ in 2014 . This area experiences the typical agro-climate of Korea where major crop fields are used for rice production. Annual mean precipitation was about $1,393 \mathrm{~mm}$ raining approximately $45 \%$ of the time (5.1 sunshine hours per day), from July to August (monsoon season) when most rice plants are in the reproductive phase. During the rice growing season, mean temperature is given as an average between May and October $\left(21.8^{\circ} \mathrm{C}\right)$ whereas minimum and maximum are given between May and August $\left(13.2^{\circ} \mathrm{C}\right.$ and $30.8^{\circ} \mathrm{C}$ ), respectively (Korea Meteorological Administration, 2014).

\section{Field level phytotron for temperature manipulation}

Four phytotrons were each built on a unit plot of $20 \mathrm{~m} \times 5 \mathrm{~m}$ by erecting semi-circular (tunnel-shape) steel frame on the ground and then covering it with a thin clear plastic sheet to elevate the inside temperature. A temperature control device was engineered using sensors to automatically open and close the ventilation of plastic windows to pre-calculated variable apertures to allow for exchange of air which maintained desired elevation of temperatures (ambient and, $0.8^{\circ} \mathrm{C}, 1.9^{\circ} \mathrm{C}$, and $3.4^{\circ} \mathrm{C}$ above ambient level). Sensors in the phytotron measured temperature every 10 second and measured values were stored inside a cell phone system. Light intensity was similar across the phytotrons. A heater with a digital temperature sensor was installed in each phytotron, and the temperature was maintained at $0.8^{\circ} \mathrm{C}$, $1.9^{\circ} \mathrm{C}$, and $3.4^{\circ} \mathrm{C}$ above the ambient temperature during



Fig. 1. Daily temperatures in the four phytotrons during the rice growing season. the experiment. One phytotron was maintained at ambient temperature as a control. Phytotrons were set to maintain temperatures at ambient, ambient $+0.8^{\circ} \mathrm{C}$, ambient $+1.9^{\circ} \mathrm{C}$, and ambient $+3.4^{\circ} \mathrm{C}$, simulating the temperature variation that could be observed with global climate change. The actual mean daily temperatures in the phytotrons for these temperature regimes were $21.4^{\circ} \mathrm{C}$, $22.3^{\circ} \mathrm{C}, 23.2^{\circ} \mathrm{C}$, and $24.5^{\circ} \mathrm{C}$, which were $0^{\circ} \mathrm{C}, 0.9^{\circ} \mathrm{C}$, $1.8^{\circ} \mathrm{C}$, and $3.2^{\circ} \mathrm{C}$, respectively, above ambient temperature (Fig. 1). The experiments were conducted in a randomized complete block design with four replications.

\section{Plant material}

Seeds of one rice cultivar (Dongjin 1) and three annual paddy weeds Echinochloa crus-galli, Monochoria vaginalis and Ludwigia prostrata, previously harvested in the experimental field of the National Institute of Crop Science Korea in 2013, were sown at one seed per cell in plastic trays filled with upland rice field soil. Thirteen seedlings of each rice and weed species were transplanted at the 3-4-leaf stage into prepuddled soils of phytotron on a $2 \mathrm{~m} \times 6 \mathrm{~m}$ experimental plots with four replicates. The plots were arranged randomly with $50 \mathrm{~cm}$ space among each other. Each plant was arranged with $3 \mathrm{~cm}$ and $6 \mathrm{~cm}$ space for investigations 10 days and 20 days after transplanting, respectively. Chemical fertilizers (Namhae Chemical Corp., Korea) were applied at $210 \mathrm{~kg} \mathrm{~N}, 170 \mathrm{~kg}$ P, and $170 \mathrm{~kg} \mathrm{~K}$ $\mathrm{ha}^{-1}$ in the form of urea, diammonium phosphate, and sulphate of potash, respectively. All the fertilizers except urea were applied during final land preparation. Urea was applied in three splits (30\% at 10 days after transplanting (DAT), 30\% at 30 DAT, and $40 \%$ at panicle initiation stage). Black plastic film was applied on the surface of the plots to block emergence of any other weeds. After transplanting of rice and weed seedlings, water level was maintained at $2-3 \mathrm{~cm}$ on the surface of the plot. Leaf area and leaf stage were investigated 60 days after transplanting. Plant height and dry weight were investigated at 10 day intervals from 30 days to 120 days after transplanting. The leaf area was measured using a leaf area meter (LI-3100C, LI-COR, USA). For dry weight assessment, plants were gently pulled out from a plot and excessive soil was removed from roots by gentle rinsing with clean water. Plants were then softly wrapped with clean paper towels and placed in an electric oven drier at $72^{\circ} \mathrm{C}$ for three days prior to measuring the dry weight.

\section{Statistical analysis}

Data on plant height, dry weight, leaf numbers, and leaf area were subjected to one-way ANOVA using the SPSS software and means were compared by Duncan's Multiple Range Test. Non-linear regression analysis of accumulative dry weight was performed using log-logistic equations (Streibig., 1988; Seefeldt et al., 1995):

$$
y=C+\frac{\mathrm{D}-\mathrm{C}}{1+\exp \{b[\log (x)-\log (H)]\}}
$$


where $y$ represents dry weight at growth rate $x$ and $C, D, b$, and $H$ are empirically derived constants. $C$ is the lower limit, $D$ the upper limit, $b$ the slope at the $H$, and $H$ the time required for $50 \%$ of growth.

\section{RESULTS AND DISCUSSION}

It was observed that all plants grew rapidly under elevated temperatures at 60 DAT while the growth rate of annual paddy weeds was higher than that of rice and the greatest increase in leaf stage, leaf area, plant height and dry weight were obtained at ambient $+3.4^{\circ} \mathrm{C}$ (Table 1 , Table 2). The total number of leaves of rice was 1.41 times higher at ambient $+3.4^{\circ} \mathrm{C}$ than it was at ambient whereas the total numbers of leaves of E. crus-galli, $M$. vaginalis, and L. prostrata were, respectively, 1.63, 3.22 , and 2.94 times higher at ambient $+3.4^{\circ} \mathrm{C}$ than they were at ambient. Especially, M. vaginalis showed the highest increase in the total number of leaves at ambient $+0.8^{\circ} \mathrm{C},+1.9^{\circ} \mathrm{C}$, and $+3.4^{\circ} \mathrm{C}$ compared to those of other weed species and rice. Likewise, L. prostrata showed the second highest increase in the total number of leaves at ambient $+0.8^{\circ} \mathrm{C},+1.9^{\circ} \mathrm{C}$, and $+3.4^{\circ} \mathrm{C}$ as well (Table 1 ). Leaf areas of rice were 2.58 times higher at ambient $+3.4^{\circ} \mathrm{C}$ than they were at ambient whereas those of $E$. crus-galli were 1.92 times higher than leaf areas at ambient, which was the smallest increase rate at ambient $+3.4^{\circ} \mathrm{C}$. Leaf areas of the other two weed species $M$. vaginalis and $L$. prostrata were, respectively, 3.55 and 3.57 times higher at ambient $+3.4^{\circ} \mathrm{C}$ than they were at ambient. L. prostrata also showed the highest increase rates of leaf areas at all elevated temperature conditions (Table 2). Therefore, there was a strong positive relation between growth parameters observed at 60 DAT and temperature increase. Elevated temperature induced a distinctive increase in the total number of leaves and leaf areas of $M$. vaginalis and L. prostrata compared to those of rice.

Plant height and dry weight of rice and annual paddy weed species were investigated under elevated temperatures at 120 DAT (Table 3). Plant heights of rice were 1.28 times higher at ambient $+3.4^{\circ} \mathrm{C}$ than they were at ambient while plant heights of E. crus-galli, M. vaginalis, and L. prostrata were, respectively, 1.46, 1.78, and 1.69 times higher at ambient $+3.4^{\circ} \mathrm{C}$ than they were at ambient. All weed species showed greater rates of plant height increase at ambient $+0.8^{\circ} \mathrm{C},+1.9^{\circ} \mathrm{C}$, and $+3.4^{\circ} \mathrm{C}$ compared to those of rice. M. vaginalis showed the highest increase rates of plant heights at all elevated temperature conditions (Table 3). A rapid increase of dry weight of rice and annual paddy weed species was detected under the elevated temperatures (Fig. 2). Based on the non-linear regression analysis of accumulative dry weight of rice and three annual weeds, the estimated maximum dry weight of rice at ambient $+3.4^{\circ} \mathrm{C}$ was 1.73 times higher than at ambient while dry weights of E. crus-galli, M. vaginalis, and L. prostrata were, respectively, 1.71, 1.64, and 2.86 times higher at ambient $+3.4^{\circ} \mathrm{C}$ than they were at ambient. L. prostrata showed the highest and second highest increase rates of dry weight at ambient +3.4 and $+1.9^{\circ} \mathrm{C}$, respectively (Fig. 2).

A previous study in Korea showed that $M$. vaginalis and Scirpus juncoides emerged 1 and 3 days faster, respectively, under temperature conditions elevated by $3^{\circ} \mathrm{C}$, which also conferred advanced growth to these weed species (Park et al., 2010). Similarly, Eleocharis kuroguwai emerged 1-2 days earlier and reached the 5

Table 1. Leaf stage of rice and three paddy weed species under elevated temperatures at 60 days after transplanting

\begin{tabular}{lcccc}
\hline \multicolumn{1}{c}{ Total number of leaves } & & \\
\hline \multicolumn{1}{c}{ Plant Species } & Ambient & Ambient $+0.8^{\circ} \mathrm{C}$ & Ambient $+1.9^{\circ} \mathrm{C}$ & Ambient $+3.4^{\circ} \mathrm{C}$ \\
\hline Oryza sativa & $7.3 \pm 0.3 \mathrm{a}$ & $8.0 \pm 0.0 \mathrm{ab}$ & $8.8 \pm 0.3 \mathrm{~b}$ & $10.3 \pm 0.8 \mathrm{c}$ \\
Echinochloa crus-galli & $6.0 \pm 0.0 \mathrm{a}$ & $7.0 \pm 0.0 \mathrm{ab}$ & $7.3 \pm 0.3 \mathrm{a}$ & $9.8 \pm 0.9 \mathrm{~b}$ \\
Monochoria vaginalis & $62.5 \pm 3.3 \mathrm{a}$ & $87.5 \pm 2.7 \mathrm{~b}$ & $131 \pm 9.4 \mathrm{c}$ & $201 \pm 12.0 \mathrm{~d}$ \\
Ludwigia prostrata & $42.5 \pm 2.3 \mathrm{a}$ & $58.2 \pm 2.2 \mathrm{ab}$ & $76.9 \pm 5.5 \mathrm{~b}$ & $125 \pm 16.1 \mathrm{c}$ \\
\hline
\end{tabular}

Values with different letters within the same row differ significantly $(\mathrm{p}<0.05)$

Table 2. Leaf areas of rice and three paddy weed species under elevated temperatures at 60 days after transplanting

\begin{tabular}{lcccc}
\hline \multicolumn{4}{c}{ Leaf area $\left(\mathrm{cm}^{2}\right)$} & \\
\hline \multicolumn{1}{c}{ Plant species } & Ambient & Ambient $+0.8^{\circ} \mathrm{C}$ & Ambient $+1.9^{\circ} \mathrm{C}$ & Ambient+3.4 ${ }^{\circ} \mathrm{C}$ \\
\hline Oryza sativa & $158 \pm 7.7 \mathrm{a}$ & $207 \pm 6.1 \mathrm{a}$ & $272 \pm 19.2 \mathrm{~b}$ & $408 \pm 34.1 \mathrm{c}$ \\
Echinochloa crus-galli & $295 \pm 6.6 \mathrm{a}$ & $325 \pm 5.9 \mathrm{a}$ & $383 \pm 18.0 \mathrm{a}$ & $567 \pm 58.4 \mathrm{~b}$ \\
Monochoria vaginalis & $96.8 \pm 2.2 \mathrm{a}$ & $105 \pm 1.2 \mathrm{a}$ & $181 \pm 10.1 \mathrm{~b}$ & $344 \pm 36.2 \mathrm{c}$ \\
Ludwigia prostrata & $205 \pm 4.9 \mathrm{a}$ & $287 \pm 31.4 \mathrm{a}$ & $497 \pm 64.4 \mathrm{~b}$ & $731 \pm 30.9 \mathrm{c}$ \\
\hline
\end{tabular}

Values with different letters within the same row differ significantly $(p<0.05)$ 
Table 3. Plant height and dry weight of rice and three paddy weed species under elevated temperature conditions 120 days after transplanting

\begin{tabular}{|c|c|c|c|}
\hline Species & Temperature & Plant height $(\mathrm{cm})$ & Dry weight (g) \\
\hline \multirow{4}{*}{ Oryza sativa } & Ambient & $81.3 \pm 5.41 \mathrm{a}$ & $33.2 \pm 2.09 \mathrm{a}$ \\
\hline & Ambient $+0.8^{\circ} \mathrm{C}$ & $90.5 \pm 2.50 \mathrm{ab}$ & $40.7 \pm 2.52 \mathrm{ab}$ \\
\hline & Ambient $+1.9^{\circ} \mathrm{C}$ & $97.1 \pm 1.09 \mathrm{bc}$ & $48.3 \pm 3.95 \mathrm{bc}$ \\
\hline & Ambient $+3.4^{\circ} \mathrm{C}$ & $103.8 \pm 2.29 \mathrm{c}$ & $53.1 \pm 1.92 \mathrm{c}$ \\
\hline \multirow{4}{*}{ Echinochloa crus-galli } & Ambient & $88.9 \pm 3.39 \mathrm{a}$ & $47.2 \pm 2.49 \mathrm{a}$ \\
\hline & Ambient $+0.8^{\circ} \mathrm{C}$ & $106.0 \pm 11.0 \mathrm{ab}$ & $58.9 \pm 2.02 \mathrm{~b}$ \\
\hline & Ambient $+1.9^{\circ} \mathrm{C}$ & $121.2 \pm 5.54 \mathrm{bc}$ & $66.3 \pm 2.14 \mathrm{c}$ \\
\hline & Ambient $+3.4^{\circ} \mathrm{C}$ & $129.5 \pm 2.02 \mathrm{c}$ & $81.3 \pm 2.17 \mathrm{~d}$ \\
\hline \multirow{4}{*}{ Monochoria vaginalis } & Ambient & $21.8 \pm 2.13 \mathrm{a}$ & $13.0 \pm 1.58 \mathrm{a}$ \\
\hline & Ambient $+0.8^{\circ} \mathrm{C}$ & $30.5 \pm 1.44 \mathrm{ab}$ & $14.7 \pm 2.19 \mathrm{a}$ \\
\hline & Ambient $+1.9^{\circ} \mathrm{C}$ & $34.9 \pm 2.70 \mathrm{bc}$ & $16.7 \pm 2.19 \mathrm{ab}$ \\
\hline & Ambient $+3.4^{\circ} \mathrm{C}$ & $38.9 \pm 2.26 \mathrm{c}$ & $22.5 \pm 2.18 \mathrm{~b}$ \\
\hline \multirow{4}{*}{ Ludwigia prostrata } & Ambient & $99.3 \pm 2.78 \mathrm{a}$ & $23.8 \pm 0.44 \mathrm{a}$ \\
\hline & Ambient $+0.8^{\circ} \mathrm{C}$ & $118.5 \pm 4.25 \mathrm{~b}$ & $26.0 \pm 0.58 \mathrm{a}$ \\
\hline & Ambient $+1.9^{\circ} \mathrm{C}$ & $156.7 \pm 2.67 \mathrm{c}$ & $57.0 \pm 3.51 \mathrm{~b}$ \\
\hline & Ambient $+3.4^{\circ} \mathrm{C}$ & $167.8 \pm 3.30 \mathrm{~d}$ & $66.3 \pm 2.85 \mathrm{c}$ \\
\hline
\end{tabular}

Values with different letters within the same column differ significantly $(p<0.05)$
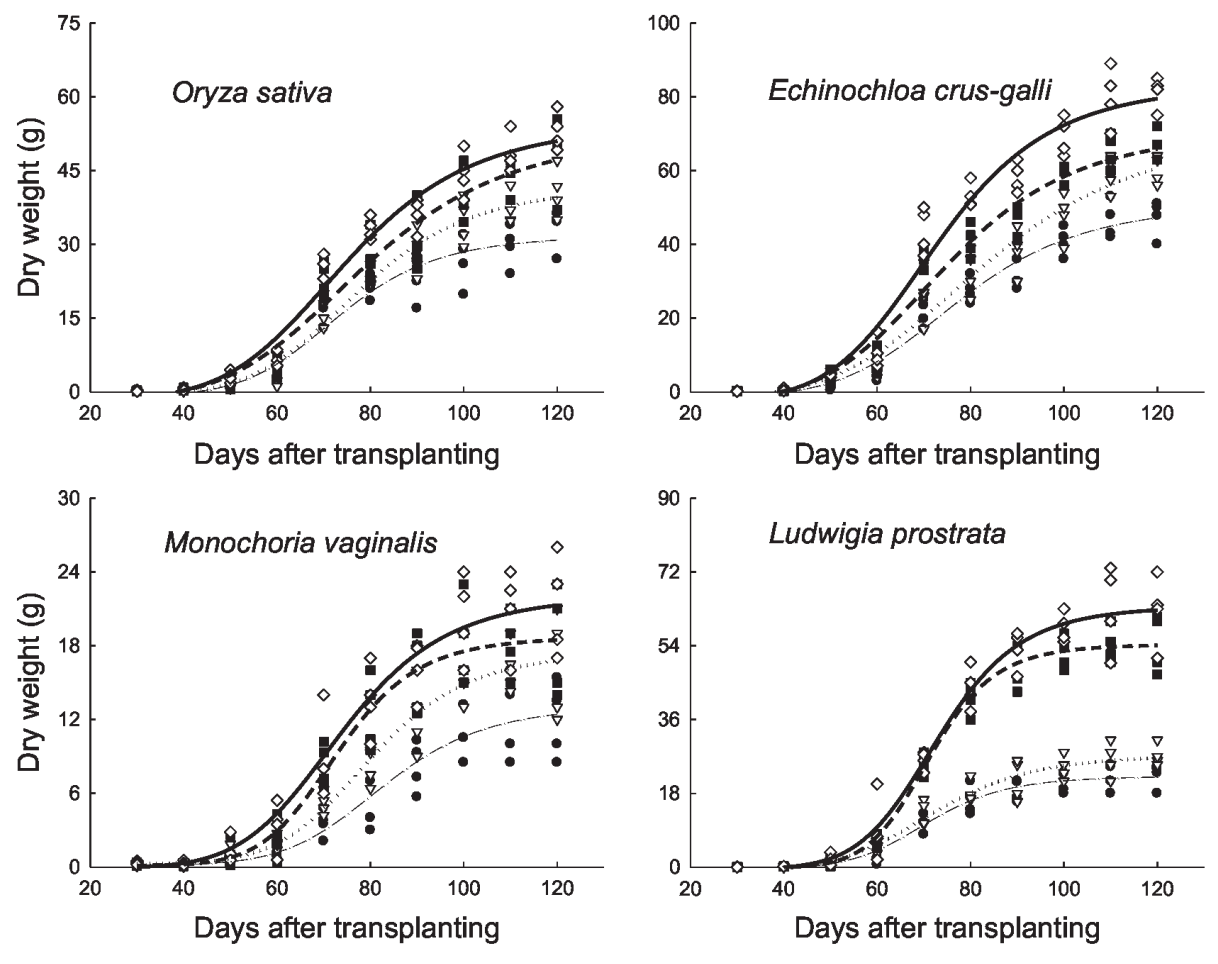

Fig. 2. Dry weight of rice and three annual paddy weeds grown under the elevated temperature regimes. 
leaf stage 2-3 days earlier under temperature conditions elevated by $2^{\circ} \mathrm{C}$ (Kim et al., 2010). Furthermore, Kwon et al. (2013) analyzed factors related to the germination temperatures of 80 weed species in paddy fields of Korea and reported that positive effects of global warming on weeds, such as earlier germination and increased germination range, would decrease crop productivity by raising competition between weeds and crops. According to Kathiresan et al. (2016), climatic factors also affect the invasive traits of weeds and play a critical role in the establishment of weed species in different parts of the world.

Taken together in this study, elevated temperatures promote the growth of $M$. vaginalis and L. prostrata more than that of E. crus-galli and rice. M. vaginalis showed an increase in the total number of leaves and plant heights while $L$. prostrata showed increased leaf areas and dry weights under elevated temperatures. From the results of this study, we can conclude that rice and weed population responses would be altered under elevated temperature conditions. Rice yield would be affected by temperature increases, but weeds would remain an important yield-threatening factor. Therefore, the impact of climate change on crops and weeds will be an important issue for agricultural production and food security in Korea. Our study suggests that temperature could play an important role in the growth of rice and weeds in paddy fields, but further study is needed to examine yield potential under elevated temperatures.

\section{ACKNOWLEDGMENT}

This work was carried out with the support of the "Cooperative Research Program for Agriculture Science \& Technology Development (Project No. PJ010526032016)", Rural Development Administration, Republic of Korea.

\section{REFERENCES}

Horie T., J. T. Baker, H. Nakagawa, T. Matsui and H. Y. Kim 2000 Crop ecosystem responses to climate change: rice. In: Reddy K. R. and H. F. Hodges (eds.), Climate Change and Global Crop Productivity. CAB international, New York, USA

IPCC 2013 Climate Change 2013: The Physical Science Basis, Working Group 1: Contribution the Fifth Assessment Report of the Intergovernmental Panel on Climate Change. Cambridge University Press, New York, USA

Jagadish S. V. K., P. Q. Craufurd, and T. R. Wheeler 2007 High temperature stress and spikelet fertility in rice (Oryza sativa L.). J. Exp. Botany., 58: 1627-1635

Kathiresan R. and G. Gualbert 2016 Impact of climate change on the invasive traits of weeds. Weed Biol. \& Manag., 16: 59-66

Kim H. Y., T. Horie, H. Nakagawa and K. Wada 1996 Effects of elevated $\mathrm{CO}_{2}$ concentration and high temperature on growth and yield of rice. Jpn. J. Crop Sci., 65: 644-651

Kim J. W, B. C. Moon, S. H. Lim, J. H. Chung and D. S. Kim 2010 Prediction of seedling emergence and early growth of Eleocharis kuroguwai Ohwi under elevated temperature.
Kor. J. Weed Sci., 30: 94-102

Korea Meteorological Administration 2014 Monthly weater report. Korea Meteorological Administration Seoul, Korea

Kwon Y. S., N. Chung, M. J. Bae, F. Li, T. S. Chon, M. H. Kim, Y. E. Na and Y. S. Park 2013 Evaluation of global warming effects on the geographical distribution of weeds in paddy fields by characterizing germination time and morphological factors. Ecol. Inform., 17: 94-103

Liu X., J. Jian, W. Guanghua and S. J. Herbert 2008 Soybean yield physiology and development of high-yielding practice in Northeast China. Field Crop Res., 105: 157-171

Matsui T., O. S. Namuco, L. H. Ziska and T. Horie 1997 Effects of high temperature and $\mathrm{CO}_{2}$ concentration on spikelet sterility in indica rice. Field Crops Res., 51: 213-219

Ohe I., K. Saitoh and T. Kuroda 2007 Effects of high temperature on growth, yield and dry-matter production of rice grown in the paddy field. Plant Prod. Sci., 10: 412-422

Osada A., V. Saciplapa, M. Rahong, S. Dhammanuvong and H. Chakrabandho 1973 Abnormal occurrence of empty grains of indica rice plants in the dry, hot season in Thailand. Proc. Crop Sci. Soc. Jpn., 42: 103-109

Park J. E., I. Y. Lee, B. C. Moon, C. S. Kim, T. A. Park, S. T. Lim, J. R. Cho, S. M. Oh, I. B. Im, J. B. Hwang and Y. C. Ku 2002 Occurrence characteristics and dynamics of weed flora in paddy rice field. Kor. J. Weed Sci., 22: 272-279 (In Korean)

Park M. W., J. W. Kim, S. H. Lim, I. Y. Lee and D. S. Kim 2010 Prediction of seedling emergence and early growth of Monochoria vaginalis and Scirpus juncoides under elevated temperature. Kor. J. Weed Sci., 30: 103-110

Patterson D. T., C. R. Meyer, E. P. Flint and P. C. Quimby 1979 Temperature responses and potential distribution of itchgrass (Rottboellia exaltata) in the United States. Weed Sci., 27 $77-82$

Prasad P. V., K. J. Boote, L. H. Allen, J. E. Sheehy and J. M. G. Thomas 2006 Species, ecotype and cultivar differences in spikelet fertility and harvest index of rice in response to high temperature stress. Field Crops Res., 95: 398-411

Rao A. N., I. J. Johnson, B. Sivaprasad, J. K. Ladha and A. M. Mortimer 2007 Weed management in direct-seeded rice. Adv. Agron., 93: 153-255

Rodenburg J. and D. E. Johnson 2009 Weed management in rice based cropping systems in Africa. Adv. Agron., 103: 149-218

Rosenzweig C., A. Iglesias, X. B. Yang, P. R. Epstein and E. Chivian 2001 Climate change and extreme weather events: implications for food production, plant diseases, and pests. Global Change Hum. Health., 2: 90-104

Seefeldt S. S., J. E. Jensen and E. P. Fuerst 1995 Log-logistic analysis of herbicide dose-response relationships. Weed Technol., 9: 218-225

Streibig J. C 1988 Herbicide bioassay. Weed Res., 28: 479-484

Sung J. K., S. Y. Lee, Y. J. Lee, S. K. Ha and Y. K. Sonn 2014 Effect of high temperature on mineral uptake, soluble carbohydrates partitioning and cucumber yield. CNU J. Agric. Sci., 41: 291-298

Wolfe W., L. Ziska, C. Petzoldt, A. Seaman, L. Chase and K. Hayhoe 2008 Projected change in climate thresholds in the northeastern U.S.: implications for crops, pests, livestock, and farmers. Mitigation and Adaptation Strategies for Global Change, 13: $555-575$

Won O. J., K. W. Park, S. H. Park, M. Y. Eom, K. S. Hwang, Y. T. Kim and J. Y. Pyon 2015 Herbicidal efficacy of carfentrazone-ethyl mixtures in direct-seeding flooded rice. CNU J. Agric. Sci. 42: 87-92 (In Korean)

Ziska L. H., P. A. Manalo and R. A. Ordonez 1996 Intraspecific variation in the response of rice (Oryza sativa L.) to increased $\mathrm{CO}_{2}$ and temperature: growth and yield response of 17 cultivars. J. Exp. Botany., 47: 1353-1359 